\title{
Idiopathic hirsutism - medical and psychological aspects
}

\author{
Grażyna Jarząbek-Bielecka', Katarzyna Warchoł-Biedermann², Witold Kędzia ${ }^{3}$ \\ ${ }^{1}$ Clinic of Gynecology of the Department of Perinatology and Gynecology, Division of Developmental Gynecology and \\ Sexuology of the Department of Perinatology and Gynecology, Poznan University of Medical Sciences, Poland \\ 2 Department of Clinical Psychology, Poznan University of Medical Sciences, Poland \\ ${ }^{3}$ Division of Gynecology, Department of Perinatology and Gynecology, Poznan University of Medical Sciences, Poland
}

\begin{abstract}
Introduction. Hirsutism is a condition which results in excess of male pattern hair growth - the androgen dependent hair in females. Excessive hair growth usually starts around puberty. The aim of this study was to show the significance of hormonal diagnosis in female adolescent hirsute patients.

Material and methods. The material consisted of medical documentation of 128 female adolescent patients aged 13-22 years who came for a consultation because of excessive male pattern hair growth (second degree of hirsutism according to the Ferriman-Gallwey scale) which they considered unacceptable. The history was indicative of considerable discomfort, decreased mood in subjects and low self-esteem (especially regarding patient's femininity).

Results. Results of the analysis were confronted with the results of a group of an equal number of participants. Conclusions. Hormonal tests in female patients with hirsutism were proven to constitute a major diagnostic element allowing for correct diagnosis of the cause of hirsutism, planning further tests and treatment methods. Considering its causes and effects, hirsutism in adolescent patients is a serious concern for developmental gynecology. This disorder is a endocrinological or gynecological problem, which influences patient's well-being.
\end{abstract}

Keywords: hair, gynecology, sexuology, girl, women.

\section{Introduction}

Hirsutism is a condition which results in of excess male pattern hair growth - the androgen dependent hair in females. Excessive hair growth usually starts around puberty [1-5].

\section{Aim}

The aim of this study was to show the significance of hormonal diagnosis in female adolescent hirsute patients.

\section{Material and methods}

The material consisted of medical documentation of 128 female adolescent patients aged 13-22 who came for a consultation because of excess male pattern hair growth (second degree of hirsutism according to the Ferriman-Gallwey scale) which they considered unacceptable. The history was indicative of considerable discomfort, decrease of mood in subjects and them experiencing feminity inferiority complex.

The degree of hirsutism was assessed with the use of Ferriman-Gallwey scale which rates hair growth from 0 to 4 points in twelve locations. Male pattern hair growth is diagnosed if one scores more than eight points on the scale:

- 8-16 points - moderate hirsutism,

- 16-36 points - severe hirsutism.

The statistical analysis by way of Chi-square test and Fisher-Freeman-Halton test has demonstrated $p=0.0213$. 


\section{Results}

The results are presented in the Table 1.

\section{Discussion}

Clinical observations show that hirsurism, which is the masculine type hair growth in females influence patient's self-esteem, their feelings related to gender identity or may even adversely affect their sexual relations [17].

Hirsutism is a hair growth problem in women characterized by unwanted and excessive hair production [6-11].

The analysis has shown the importance of diagnostic aspect of hormonal testing in clinical cases of hirsutism [12-14]. As we mentioned in the introduction, hormonal testing in hirsutism is used to confirm clinical observation of hyperandrogenism and to find the source of excessive androgen production [15-18]. Here, the most important examinations include evaluation of testosterone serum concentration (as testosterone is the main circulating androgen) [19-22].

The sources of circulating testosterone in females include the following:

- ovarian origin (probably ovarian stroma) - 5-20\%,

- adrenal origin - 0-30\%,

- the result of peripheral transformation - 50-70\%.

Medical test results do not confirm virilizing tumors or congenital hydroxylation defects.

Patients whose serum LH concentrations are respectively higher than FSH concentrations are hirsute as a result of polycystic ovarian syndrome confirmed by ultrasound scan of ovaries.

Polycystic ovary syndrome (PCOS) affects 5-10\% of the population of women, and the spectrum of its symptoms such as obesity, hirsutism, skin problems, and finally fertility problems has a huge negative impact on the individual's psychological and interpersonal functioning [21, 22].

According to literature, PCOS can be found in $10 \%$ of women in reproductive age. Despite 70 years of research on $\mathrm{PCOS}$, its etiopathogenesis remains unexplained.

The relation between patient's lifestyle and the course and effects of her disease, which has been confirmed in literature, gives reasons to continue research aimed at starting preventive actions as early as possible. From a patient's point of view clinical symptoms accompanying PCOS may adversely influence her mental health and sexuality. These women often suffer from low self-esteem and have a negative image of their femininity. Ekback et al. (2009) interviewed women who suffered from hirsutism due to polycystic ovarian syndrome. The study has confirmed that women with excessive male pattern hair growth, the participants of the study had a negative image of their bodies which they detested and experienced as a prison.

Additionally, elevated testosterone levels may be a risk factor in depressive episodes, which in turn have impact on quality of patient's family life and her effectiveness at work.

Table 1. The tests used include Chi-square test for independence or Fisher-Freeman-Halton test

\begin{tabular}{lccc}
\hline \multicolumn{1}{c}{ Hormone concentrations } & Experimental group Mean \pm SD & $\begin{array}{c}\text { Control } \\
\text { Mean } \pm \text { SD }\end{array}$ & $p$-value \\
\hline FSH & $5.253 \pm 2.25$ & $5.110 \pm 1.94$ & $p=0.301$ \\
\hline LH & $9.517 \pm 2.25$ & $9.930 \pm 1.94$ & $p=0.00000$ \\
\hline E2 & $84.180 \pm 65.29$ & $57.812 \pm 38.72$ & $p=0.00000$ \\
\hline PRL & $22.867 \pm 20.25$ & $14.687 \pm 7.02$ & $p=0.000000$ \\
\hline Total testosterone & $0.719 \pm 0.26$ & $0.491 \pm 0.29$ & $p=0.00001$ \\
\hline DHEA-S & $10.224 \pm 5.04$ & $6.651 \pm 3.02$ & $p=0.0001$ \\
\hline SHBG & $41.97 \pm 20,94$ & $66.572 \pm 0,042$ & $p=0.042$ \\
\hline
\end{tabular}

No correlation was found

Table 2. Plasma total testosterone concentrations

\begin{tabular}{|c|c|c|}
\hline & $\begin{array}{l}\text { Above } 3.4 \mathrm{nmol} / \mathrm{l} \\
\quad>1 \mathrm{ng} / \mathrm{ml}\end{array}$ & $\begin{array}{c}\text { Below } 3.4 \mathrm{nmol} / \\
\quad<1 \mathrm{ng} / \mathrm{ml}\end{array}$ \\
\hline $\begin{array}{l}\text { Virilizing adrenal or ovarian tumors } \\
\text { Total testosterone concentration } \\
>6.8 \mathrm{nmol} / \mathrm{l}=>2 \mathrm{ng} / \mathrm{dl} \\
\text { Extremely elevated androstenedione, DHEA } \\
\text { or DHEA-S levels } \\
\text { Localizing examinations of the tumor }\end{array}$ & $\begin{array}{l}\text { Congenital hydroxylation defects } \\
\text { Androstenedione, } \\
\text { DHEA, DHEA-S and total testosterone concentrations slightly elevated } \\
\text { (50-100\% higher) } \\
\text { Extremely elevated progesterone and 17-hydroxyprogesterone levels in response } \\
\text { to ACTH (10 times as much) }\end{array}$ & $\begin{array}{l}\text { PCOS } \\
\text { Enlarged ovaries } \\
\text { LH/FSH elevated } \\
\text { Elevated PRL } \\
\text { Lowered TBG } \\
\text { Elevated free T }\end{array}$ \\
\hline
\end{tabular}


Patients whose hormone concentrations remain within the normal reference ranges were diagnosed with idiopathic hirsutism (these girls were found to have a correct ovary structure - which is not the subject of this paper)

Hirsutism is caused by three main reasons:

- nonandrogenic factors are the ones that are not related to disproportionate androgen activity,

- result of androgen excess,

- idiopathic hirsutism.

Since androgens are the main hormones that affect hair production and development in humans, the most common cause of hirsutism is traced to androgen malfunction. Idiopathic hirsutism is the second most common cause of hirsutism after polycystic ovarian syndrome (PCOS), which is associated with androgen dysfunction. Idiopathic hirsutism accounts for approximately five to 17 percent of hirsute cases.

Idiopathic hirsutism can be defined as excessive terminal hair production in a male-like pattern in androgen-receptive body parts of patients who show no signs of endocrine or androgen disorders. This kind of hirsutism occurs in the presence of regular ovulation and normal androgen levels.

In hirsute patients, one of the crucial tasks is to conduct a through examination in order to distinguish idiopathic hirsutism from other forms of hirsutism. Though a lot more research needs to be done about its pathophysiology, patients with this kind of hirsutism have a probable excessive peripheral 5a-reductase action in skin and hair follicle, other variations in androgen metabolism or greater sensitivity of the androgen receptor.

To understand any kind of hirsutism it is first necessary to know a bit about human hair biology [11].

Human hair follicles first form in a human fetus. The number of human hair follicles that grow, which is $3-5$ million ( $20 \%$ of which is in the scalp), is genetically predetermined.

To understand hirsutism better, one needs to know the three human hair types and their life cycle:

- lanugo hair: This soft, downy hair is first formed in the fetal stage in the mother's womb and is lost in late gestation or early postpartum stage,

- vellus hair: It is non-pigmented, soft and short and occurs in the seemingly hairless body regions,

- terminal hair: This is pigmented, dense, coarse and longer than vellus hair and composes the eyebrows, eyelashes, scalp hair, the pubic hair and axillary hair, etc.

The permanent conversion and development of vellus to terminal hair is a normal physiological process triggered by androgens, testosterone and dihydrotestosterone (DHT) in body areas that are androgen sensitive. This cycle normally begins at puberty, continues through adult life and gradually lessens with age and reproductive capacity in both sexes.

The normal life cycle of hair is made up of three alternating stages:

- anagen stage: Growth,

- catagen phase: Involution,

- telogen phase: Rest.

Primary symptoms of idiopathic hirsutism are excessive terminal hair growth in androgen-sensitive body areas. However, menses (i.e. ovulation) and circulating androgen levels remain unaffected. Moreover, studies about this kind of hirsutism found altered functioning of androgen receptors and an altered androgen metabolism. It was found that in the peripheral blood lymphocytes of certain patients with idiopathic hirsutism, the longer of the two androgen receptor alleles was "preferentially methylated" (and hence dysfunctional). Hence, experts suggest that it is probable that genetic modifications of the androgen receptor function and possibly 5a-reductase functions can alter the manifestation of hirsutism. Around 40 per cent of eumenorrheic hirsute women show signs of anovulation and hence they are diagnosed for polycystic ovary syndrome (PCOS) and not idiopathic hirsutism [11].

On the basis of analysis of literature and research results it should be concluded that, most importantly, hormone concentrations in certain types of hirsutism are the following:

- idiopathic type - hormone levels usually remain within the normal reference ranges,

- ovarian type - elevated free testosterone levels (LH/FSH concentration ratio in PCOS > 2.5),

- adrenal type - elevated DHEA-S concentrations and congenital adrenal hyperplasia, (CAH) - elevated 17-alpha-hydroxy-progesterone concentrations,

- mixed type - elevated DHEA-S and free testosterone concentrations.

Although it has not been a topic of this paper, one must bear in mind that differential diagnostics by way of the so-called dynamic tests are used except for physical examination, medical interview and basic hormonal testing $[6,7]$.

According to literature, patients with elevated DHEA-S and free testosterone concentrations undergo a Dexamethasone Supression Test while ACTH stimulation test must be used to confirm the diagnosis of congenital adrenal hyperplasia. In treatment of hirsutism best results are achieved by psychotherapy connected 
with cosmetic procedure and pharmacological therapy. Except for rare tumor cases, the role of surgery remains insignificant [8-10].

As it was mentioned in the introduction, psychological aspect of hirsutism is of particular importance especially in case of young patients because their psychosexual development takes place simultaneously with somatic development $[12,13]$.

The problem of hirsutism should be explained to adolescent girls. Although hairiness does not play an important role in physiological processes, characteristic differences in its seating arrangements in both genders are relevant for one's normal psychosexual and social functioning. Patients need consultation about their apprehensions and fears connected with the problem of hirsutism (or other hyperandrogenization characteristics). A doctor should assess patient's perception of the severity of the problem. The participants of the study had a $2^{\text {nd }}$ degree of hirsutism. Despite the fact that it was not the highest degree of hirsutism, it was the most important problem for them at the moment of consultation [14-16].

Most investigators agree that even low degree hirsutism may adversely influence self-confidence and can cause self-consciousness which in turn leads to one's withdrawal from social life and further difficulties in social life. Keegan et al. (2003) interviewed 53 women to assess psychological consequences of perceived hirsutism. Authors of the study suggested that it was not the excessive hair growth in itself but idealized cultural norms for hair growth which caused problems with sexual identity and feelings of stigma. Our results support Keegan's conclusions. All participants of our study did not accept and were deeply frustrated because of hirsutism. As it was mentioned before, it was the main reason why they sought gynecological consultation. They were observed to be highly motivated to start difficult, sometimes painful testing and treatment. In contrast to some data in literature, which claim that the patients are not concerned with their fertility, patients in the experimental group showed their apprehension and fears connected with that problem $[17,18]$. It was confirmed that from clinical point of view it was very important to talk to them about it [19-22].

Hirsutism, associated with social and psychological difficulties including anxiety, social avoidance and a confusion of gender identity and although it raises important gender issues is not only endocrinological, gynecological problem, but a psychological-sexuological too $[23,24]$.

\section{Conclusions}

Hormonal tests in female patients with hirsutism were proven to constitute a major diagnostic element allowing for correct conclusions about the cause of hirsutism, planning further tests and treatment methods.

Considering its causes and effects, hirsutism in adolescent patients is a serious concern for developmental gynecology.

Girls and women with excess hair growth need to be evaluated by a healthcare provider, especially if the hair develops or worsens rapidly, or if her relatives have comparatively less hair growth. In the vast majority of cases, hirsutism is not caused by a serious medical condition; however, the cause of hirsutism should be determined, and underlying conditions may need to be treated [21].

\section{Acknowledgements}

\section{Conflict of interest statement}

The authors declare that there is no conflict of interest in the authorship or publication of contribution.

\section{Funding sources}

There are no sources of funding to declare.

\section{References}

1. Słomko Z. Ginekologia. Podręcznik dla lekarzy i studentów. PZWL. Warszawa, 1998.

2. Hirsutism and virilization. www.medical-library.org

3. Korman E. Podstawy endokrynologii wieku rozwojowego. PZWL. Warszawa, 1999, 279-288.

4. Skałba P. Endokrynologia ginekologiczna. PZWL. Warszawa, 1993, 164-171.

5. Romer T. Endokrynologia kliniczna dla ginekologa, internisty i pediatry. PWN. Warszawa, 1998, 172-181.

6. Speroff L. Kliniczna endokrynologia ginekologiczna i niepłodności. Część 2. Endokrynologia kliniczna. MediPage. Warszawa, 2007, 573-605.

7. Beck W. Położnictwo i ginekologia. Urban\&Partner. Wrocław, 1995, 421-427.

8. Dalton M. Endokrynologia ginekologiczna. Sanmedika. Warszawa, 1997, 82-87.

9. Czekanowski R. Zarys ginekologii zachowawczej. PZWL. Warszawa, 1985, 212-214.

10. Speroff L. Kliniczna endokrynologia ginekologiczna i niepłodności. Część 1. Fizjologia rozrodu. MediPage. Warszawa, 2007.

11. www.hirsitism.com

12. Buggs C, Rosenfield RL. Polycystic ovary syndrome in adolescence. Endocrinol Metab Clin North Am. 2005; Sep;34(3):677-705.

13. Pelusi C, Pasquali R. Polycystic ovary syndrome in adolescents: pathophysiology and treatment implications. Treat Endocrinol. 2003;2(4):215-230. 
14. Jarząbek-Bielecka G, Radomski D, Loewe-Kiedrowska A. The significance of hormonal tests in female patients at the developmental age of hirsutism. In: 16th World Congress of Pediatric and Adolescent Gynecology. Montpellier, France, May 22-25, 2010. Final Programme \& Abstract Book. [B.m., 2010] s. 119 abstr. P2.2-46.

15. Burch W. Endokrynologia. Urban\&Partner. Wrocław, 1996, 114-122.

16. Mishell DR. Położnictwo i ginekologia - podstawowe problemy. Tom 3. Endokrynologia ginekologiczna. $\alpha$-medica press. Bielsko-Biała, 1996, 63-85.

17. Ekback M, Wijma K, Benzein E. It is always on my mind: women's experiences of their bodies when living with hirsutism. Health Care Women Int. 2009;30:358-372.

18. Keegan A, Liao LM, Boyle M. Hirsutism: a psychological analysis. J Health Psychol. 2003;8:327-345.

19. Conn J, Jacobs H. Leczenie hirsutyzmu w praktyce ginekologicznej. Medycyna Praktyczna. Ginekologia i Położnictwo. 1999;1(1).

20. Jakiel G. Hirsutyzm w praktyce ginekologa i dermatologa. Ginekologia po Dyplomie. 2004;6:3(30).

21. Martin KA, Chang RJ, Ehrmann DA et al. Evaluation and treatment of hirsutism. J Clin Endocrinol Metab. 2008; 93:1105.

22. Nowotnik A. Wielowymiarowość doświadczenia zespołu policystycznych jajników u kobiet w wieku rozrodczym: przegląd badań. Nowiny Lekarskie. 2012;81(3):268-272.
23. Jarząbek-Bielecka G, Loewe-Kiedrowska A, Radomski D, Paluszkiewicz A. Znaczenie badań hormonalnych u pacjentek w wieku rozwojowym z hirsutyzmem. Czas Pol Prz Nauk Zdr. 2011;3(28):294-304.

24. Keegan A, Liao LM, Boyle M. Hirsutism: a psychological analysis. J Health Psychol. 2003 May;8(3):327-345.

Acceptance for editing: 2014-12-10 Acceptance for publication: 2014-12-31

Correspondence address:

Grażyna Jarząbek-Bielecka Clinic of Gynecology of the Department of Perinatology and Gynecology

Division of Developmental Gynecology and Sexuology of the Department of Perinatology and Gynecology Poznan University of Medical Sciences 33 Polna Street, 60-535 Poznań, Poland phone: +48 618419278 email: grajarz@o2.pl 